\title{
İşitme Engelli Çocuğa Sahip Annelerin Gereksinimlerinin
}

\section{Belirienmesi}

\section{Gönïl AKCAMETE* \\ Ankara Üniversitesi}

Tevhide KARGIN

Ankara Üniversitesi

$\mathbf{E}$

ngelli çocuğun eğitiminde erken eğitim programlannın yaygınlaşmasıyla birlikte, çocuğun eğitimine ailenin katılımı her geçen gün daha da önem kazanmıştır (Cunningham, 1985; Meyers ve Blacher, 1987). Bu konuda yapılan çahş̧malarda aile katılımının yaratacağı engellerin ortadan kaldırılmaya ve aile kaלılımının arttırılmaya çalışıldığı görülmektedir (Weber ve Stoneman, 1988). Anne - babalarnn kişilik özelliklerinin, beklentilerinin, aile ilişkilerinin, sosyo - ekonomik ve kültürel özelliklerinin, destek gereksinimlerinin ve aile içi görev dağılımlarının, çocuklarının eğitim programlamna katılımlarını etkilediği belirlenmiştir. Bu nedenle, aile katılımının arttırılabilmesi için çocuğun o andaki performans düzeyinin değerlendirilmesinin yanısıra anne-baba çocuk etkileşiminin, ailenin yapısının, fonksiyonlarmmn, duygusal güçlerinin, problem çözme becerilerinin, kaynaklarının ve gereksinimlerinin belirlenmesinin önemli olduğu sonucuna varılmıştır (Robinson, Rosenberg ve Beckman, 1988; Cunningham, 1985).

Ailenin. işitme engelli çocuklan için ilk iletişim kaynağı ve dil modeli oluşturma açısından önemli bir güce sahip olduğu kabul edilmektedir (Winton, 1986; Fitzgerald ve Fischer, 1987). Bu durum ailenin rollerinde önemli değişikliklere yol açmış ve aile çocuğunun eğitiminde doğrudan görev üstlenir hale gelmiştir (Bernstein, 1993; Winton, 1986; Fiztgerald ve Fischer, 1987).

İşitme engelli çocukların eğitimini, erken dönemde aile çevresi içinde gerçekleştirmeyi hedefleyen erken eğitim programlarunın başarsl, hazırlanan programın aileye uygunluğuna bağlıdır (Robinson ve ark., 1988; McLoughlin ve Rena, 1990). Erken eğitim programlarmm aileye uygunluğunun sağlanabilmesi için, ailenin gereksinimlerinin belirlenmesi ve bu gereksinimleri karşılayacak hizmetlerin planlanması gerekmektedir. Bu planlamanın yapılabilmesi ise progranı oluşturulmadan önce tamlama aşamasında tutumlar, değerler, inançlar gibi ailenin psikolojik özellikleri ile aile - çocuk etkileşimi, kardeş etkileşimi, destek ilişkileri gibi aile ilişkilerinin belirlenmesini gerektirmektedir (Bailey ve Simeonsson, 1988).

* Yazı̧̧a Adresi: Doç. Dr. Gönül AKÇAMETE, Ankara Üniversitesi, Eğitim Bilimleri Fakültesi, Özel Eğitim Bölümü. 06590 Cebeci/ANKARA 
Ailenin gereksinimlerinin belirlenmesi; aileye sağlanacak hizmetlerin turu, içeriği, niteliği ve yonteminin seçimi açısından çok önemlidir. Hizmetlerin gereksinimleri karşılamadığı durumlarda program başarısı duşmekte, ailenin programı kabul etmesi ve programa aktif katılımı da guçleşmektedir (Bailey ve Simeonson, 1988).

Aile gereksinimlerini belirleme konusunda yapılan bir çahşmada Bailey ve Simeonsson (1988), anne-baba gereksinimlerini; bilgi gereksinimi, destek gereksinimi, çocuğun durumunu diğerlerine açıklayabilmek, toplumsal servisler, maddi gereksinimler ve ailenin işleyişi ile ilgili toplumsal gereksinimler olarak gruplamışlardır. Araştırmacılar, erken eğitim programma katılacak anne-babaların gereksinimlerini belirlemek amacıyla, bu gereksinim alanlarını içeren Aile Gereksinimlerini Belirleme Aracı (Family Needs Survey) geliştirmişler, 34 anne-babaya uygulayarak anne-babalarm en fazla ya da en az gereksinim duydukları alanları belirlemişlerdir. Hem annelerin hem de babaların, çocuklarına bir beceri ŏgretme, çocuk için uygun kurum bulma, diğer anne-babalar hakkunda yazılı materyal okuma alanlarında ortak gereksinimlerinin olduğu, annelerin aynca çocuğun engeli hakknda bilgi, diğer annebabalarla tanışma ve konuşma, kendileri için zaman ayırma ve maddi yardım konularında gereksinim belirttikleri gozlenmiştir. Yine annelerin \% $10^{\prime}$ undan azının çocuğun öğretmeni ve terapistiyle goruşme, çocuğa uygun doktor bulabilme, kilise ya da sinagogta çocuğa bakacak kimse bulma ve iş bulabilme konularnda gereksinimleri olduğu bulunmuştur (Bailey ve Simeonsson, 1988).

Işitme engelli çocukların anne-babalarının gereksinimlerinin belirlenmesine yonelik bir çalı̧̧mada Bernstein ve Barta (1988), etkili bir eğitim programı oluşturmak için anne-babaların en çok ne tur bilgilere gereksinimleri olduğunu belirlemişlerdir. Araştırmanın sonucunda anne-babaların teknik bilgiden çok, çocukları ile ilgili bilgilere gereksinim duydukları gorulmuştur. Dil gelişimini teşvik etme, çocuğun benlik algısını guçlendirme, işitme kaybının nedenleri en çok gereksinim duyulan konular arasında yer alırken; kulağın anatomisi, fizyolojisi, odyoloji gibi konular daha az onemli olarak sıralanmıştır. Ayrnca annebabaların eğitim ve disiplin konularında da bilgiye gereksinim duydukları bulunmuş̧tur.

Anne babaların gereksinimleri dikkate alınarak hazırlanan erken eğitim programlarının etkililiğini inceledikleri bir çahışmada Dunst, Johanson, Trivette ve Hamby (1988), 45 zihinsel engelli ve gelişim geriliği olan bebek ve çocukların annelerinin gereksinimleri doğrultusunda 
geliştirilen programa annelerin daha fazla zaman ve enerji harcayarak katıldıklarını ve kendilerini daha iyi hissettiklerini bulmuşlardır.

Ulkemizde işitme engelli çocuğu olan ailelerin bilgi gereksinimlerine yonelik olarak hazırlanan erken eğitim programlarının etkililiğinin incelenmesine yonelik Akçamete ve Kargın (1996) tarafindan gerçekleştirilen bir çalışmada; anne babalar en fazla bilgi gereksimi duydukları alanı, çocuğuna iletişim becerilerini oğretme konusunda "yardım" olarak işaretlemişlerdir. Gelecekteki ve şimdiki eğitim olanaklarına ilışkin bilgi gereksinimi ikinci sırasında yer alırken; uçuncu sırada engele ilişkin bilgi gereksinimi yer almıştır. Gelişim ozelliklerine iliş̧ıın bilgi gereksinimi ile cihaz kullanımına ilişkin bilgi gereksinimi anne-babaların diğer gereksinim alanlarm oluşturmuştur. Araştırmanın sonucunda belirlenen bu gereksinim alanların dikkate alarak hazırlanan erken eğitım programlarının etkili olduğu bulunmuştur.

Sucuoğlu (1995), Bailey ve Simeonsson tarafindan geliştirilen Aile Gereksinimlerini Belirleme Aracını Turkçeye çevirerek Turkçe Formunun geçerlik ve guvenirlik çalışmalarını gerçekleştirmiş, aynı çalışmada zihinsel engelli ve otistik çocuğa sahip 44 anne ile 45 babanın gereksinimlerini belirlemiştir. Araştırmanın sonucunda hem annelerin hem de babalarm ortak belirledikleri gereksinim alanlarının sırasıyla bilgi gereksinimi, destek gereksinimi ve maddi gereksinim olduğu bulunmuştur. Ayrıca aynı çahş̧mada engelli çocuğu olan anne-babalar için eğitim, terapi ve bu gibi hizmetlerin hazırlanmasında, annebabaların oncelikli gereksinimlerinin karşılanmasının uygulanacak programların başarısını arttıracağı tartışılmıştır.

Bu çalışmada işitme engelli çocuğu olan annelerin gereksinimlerinin ve bu gereksinimlere etki eden faktorlerin belirlenmesi amaçlanmıştır. Ayruca Bailey ve Simeonsson'un Aile Gereksinimlerini Belirleme Aracı'nın jşitme engelli çocuğa sahip anne grubu için de geçerlik ve guvenirlik çalışmalarının yapılması planlanmıştır.

\section{YÖN'TEM}

\section{Araştırma Grubu}

Araştırma grubunu işitme engelli çocuğa sahip 211 anne oluşturmaktadır. Yalnızca 45 babaya ulaşlabildiğinden babalar araştırma kapsamına alınmamışlardır. Ayruca 11 anne anketin tumunu yanıtla- 
madıkları ıçın araştırma dışı btrakılmıştır. Işitme engellı çocukların tumu Ankara'dakı işitme engellilerle ilgili ozel eğitim kurumlarına devam etmektedirler. Annelerin demografik ozellikleri Tablr I' de, çocukların demografik ozelhkleri ise Tablo 2 'de gosterimiştır.

Tablo 1: Ișttme Engellı Çocuğa Sahtp Annelerın Demografik Ozelltklert

\begin{tabular}{|l|l|rr|}
\hline & & \multicolumn{2}{|c|}{ Anne } \\
& & $\mathrm{n}=200)$ \\
\hline Yaş & $20 \cdot 30$ & 27 & 13,5 \\
& $31 \cdot 40$ & 115 & 57.5 \\
& $41-50$ & 45 & 22.5 \\
& 50 ve ustu & 13 & 65 \\
\hline Eğıttm & Yok & 45 & 235 \\
Durumu & Ilk & 118 & 608 \\
& Orta & 14 & 7.2 \\
& Lise & 17 & 86 \\
\hline Alle Eğıtum: & Alle Eğt Alan & 106 & 667 \\
Alip Almana & Aile Eğt Almayan & 53 & 333 \\
Durumu & & & \\
\hline
\end{tabular}

Tablo 1'de gorulduğu gibi, annelerin \% 57,5'inin $31-40$ yaş grubunda, $\% 60.8$ inm ilkokul mezunu, \%66.7'sınin daha once aile eğıtimi almış oldukları dikkati çekmektedir. Ayrıca eğitim durumunu belirleyen soruya 6 annenin, aile eğitimi alıp olmadığını belirlemeyı amaçlayan soruya da 41 annenin cevap vermedikleri Tablo I'de gorulmektedir.

Tablo 2: Işttme Engellı Çocuklarınin Demografik Ozelltklerı

\begin{tabular}{|l|l|rc|}
\hline & & \multicolumn{2}{|c|}{ Işıtme Engell çocuk } \\
& & $\mathrm{n}$ & $(\mathrm{n}=198)$ \\
\hline Cinsıyet & Kız & 91 & 459 \\
& Erkek & 107 & 541 \\
\hline Yaß̧ & 12 ve altı & 115 & 581 \\
& 13 ve ustu & 83 & 419 \\
\hline Işıtmie & Hafif & 13 & 66 \\
Kaybı & Orta & $\mathbf{1 8}$ & 91 \\
Derecesı & Orta llerı & $\mathbf{2 7}$ & 136 \\
& Ilerı & $\mathbf{4 5}$ & 379 \\
& Çok ulerı & 65 & 328 \\
\hline
\end{tabular}


Tablo 2'de araştırmaya katılan işitme engelli çocukların \% 54.1'ini erkek, \%58'ini 12 yaş ve altında yaş grubunda, \%70.7'sini ise ileri ve çok ileri derecede işitme kaybına sahip işitme engelli çocukların oluşturduğu görülmektedir. Aymca yine Tablo 2'de görüldüğü gibi işitme kaybının derecesini belirlemeye yönelik soruya 30 annenin cevap vermediği dikkati çekmektedir.

Veri Toplama Aracı: Bu çalışmada işitme engelli çocuğu olan annelerin gereksinimlerini belirleyebilmek amaciyla Bailey ve Simeonsson (1988) tarafindan geliş̧tirilen ve Sucuoğlu (1995) tarafindan çeviri, geçerlik ve güvenirlik çalışmaları yapılan "Aile Gereksinimlerini Belirleme Aracı (AGBA) kullanılmıştır. Araç iki bölümden oluşmaktadır (Bailey ve Simeonsson, 1988; Sucuoğlu, 1995):

I. Bölüm: Bu bölümde anne-babaların gereksinimlerinin farkına varabilmelerini sağlamak amacıyla altı grupta toplanmış 35 madde yer almaktadır. Birinci grupta; anne babanın bilgi gereksinimini, ikinci grupta; destek gereksinimini, üçüncü grupta; çocuğun durumunu, ailenin diğer bireylerine, komşulara ve diğer çocuklara açıklama konusundaki gereksinimlerini ifade eden maddeler bulunmaktadır. Bu bölümde yer alan her madde 1 (kesinlikle hayrr), 2 (emin değilim), 3 (kesinlikle evet) olarak yantlanmaktadır.

II. Bölüm: Bu bölümde "Lütfen ailenizin en temel beş gereksinimini sıralayınız" ile ifade edilen açık uçlu bir soru bulunmaktadır. Bu soru ile, birinci bölümde yer almayan, aile için daha özel olan gereksinimlerin belirlenmesi hedeflenmektedir.

Araçla elde edilen verilerin güvenirliği Bailey ve Simeonsson (1988) tarafından test-tekrar test yöntemiyle araştırılmış, iki değerlendirme sonucunda elde edilen puanların korelasyonunun anneler için $r=.67$, babalar için $r=.81$ olduğu bulunmuştur.

Sucuoğlu (1995), zihinsel ve otistik çocuğa sahip 44 anne ile 45 babadan toplanan verilerle yaptığı faktör analizi çalışması sonucunda, araçtaki maddelerin orijinal ölçekteki gibi 6 faktörde toplandığını, 34 olan madde sayısının 24 madde olarak belirlendiğini, aracın Cronbach Alfa iç tutarlılık katsayısının .90 olduğunu saptamıştır.*

Yapı Geçerliği: Aracın yapı geçerliğini belirlemek amacıyla faktör analizi çalışması yapılmıştır.

Faktör Analizi: İ̧̧itme engelli çocuğu olan annelerin gereksinimlerini belirlemek amacıyla yapılan bu çalışmada toplanan verilerin analizi SPSS Programı ile yapılmış ve faktör analizi çalışması işitme engelli 
çocuğu olan 200 anneden elde edilen verilere dayanarak, 24 madde üzerinden gerçekleştirilmiştir. Faktör analizinin birinci aşamasında, ölçeğin tek boyutlu olup olmadiğın saptamak için Temel Bileşenler Analizi (Principal Component Analysis) kullanılmıs, ölçek tek boyutlu görülmekle birlikte, ölçeğin faktörlerinin net olarak ortaya çkmasını sağlamak amacıyla varimaks rotasyonu yapılmıştır. Böylece birbirinden olabildiğince bağımsız faktörlere ulaşılmaya çalışılmıştır. Analiz sonucunda aracin, toplan varyansın \%62,4'ünü açılayan 6 faktörden oluştuğu gözlenmiştir. Ailenin İşleyişi, Maddi Gereksinim, Bilgi Gereksinimi, Çocuğun Durumunu Diğerlerine Açıklamak, Toplumsal Servisler ve Destek Gereksinimi olarak kavramsallaştırılan faktörlere giren maddeler ve bu maddelerin faktör yükleri Tablo $3^{\dagger}$ de yer almaktadır.

Tablo 3: AGBA'nun Faktör Yaptst

$\begin{array}{ll}\text { AGBA'nın Maddeleri } & \text { F1 } \\ \text { Ailenin İşleyişi } & \\ 1 . & .33 \\ 2 . & .40 \\ 3 . & .57 \\ 4 . & .76 \\ 5 . & .78\end{array}$

Maddi Gereksinim

6.

7.

8.

10.

.84

\section{Bilgi Gereksinimi}

11.

12.

14.

Çocuğun Durumunu Diğerlerine Açılklamak

15.

Toplumsal Servisler

Destek Gereksinimi 
Guvenirlik Çalışması:

Aracın guvenirliğini belirlemede iç tutarlık guvenirlik katsayısı Cronbach Alpha formulu ile hesaplanmış ve 6 boyuta ilişkin Alpha Katsaylam sirasiyla $.79, .78, .82, .83, .60, .43$ olarak bulunmuştur.

Altıncı boyutun Cronbach Alfa Iç tutarlılık katsayısının, diğer boyutlara gore duşuk olması bu boyuttaki madde sayısının azlığından kaynaklanmış olabilir. Elde edilen bu değerler, aracın guvenirliğinin yeterli olduğunu gostermektedir.

Verilerin Çözümlenmesi:Annelerin temel gereksinimlerini belirleyebılmek amaciyla toplanan verilerin yuzdelik değerleri bulunarak en çok ve en az gereksinim duyulan alanlar belirlenmiştir. Ayrıca annelerin gereksinimlerinin demografik ozellikler, tek yonlu varyans analizi tekniği ile $t$ testi kullanılarak incelenmiştir.

\section{BULGULAR}

Bu çalışmada oncelikle Aile Gereksinimlerini Belirleme Aracı (AGBA) uygulanarak annelerin en fazla ve en az gereksinim duydukları alanlar belirlenmiştir. Daha sonra bu gereksinimlerinin bazı demografik değişkenlerle ilişkisi araştırılmıştır.

1. Annelerin En Fazla Gereksinim Duyduklari Alanlar: Annelerin en fazla gereksinim duyduklar alanlar belirleyebilmek için, toplanan verilerin yuzdelik değerleri incelenmiştir. AGBA'daki maddeleri "kesinlikle evet" olarak yanitlayan annelerin yuzdeleri Tablo $4^{4}$ de gosterilmiştır.

Tablo 4: Annelerin AGBA Maddelerine Verdikleri Evet Cevaplarnın Yuzdelık Değerleri

F1 Ailenin İşleyişi

Anne

1. Ailem içinde, problemlerm hakkında konuşabilecegim birisine gereksinim duyuyorum.

2. Problemlerimizi tartışmak ve çozumler bulabilmek için ailemin yardıma gereksinimi vardır.

3. Ailemin, guç zamanlarda bırbirleriní nasıl destekleyeceklerıni oğrenmek için yardıma gereksinimi vardir.

4. Ailem, dinlenme/eğlenme etkinlikleri hakkında karar vermek ve yapmak için yardmma gereksinim duymaktadır.

5. Ailem, ev işleri, çocuk bakımı ve diğer işleri kimlerin yapacağ hakkında karar verebilmek için yardıma gereksinim duymaktadur. 


\section{F2 Maddi Gereksinimler}

6. Zaman zaman çocuğuma bakan bakıciya para ödeyebilmek için yardıma gereksinim duyuyorum.

7. Çocuğumun gereksinimi olan oyuncaklar alabilmek için yardıma gereksinim duyuyorum.

8. Yiyecek, ev kirası, tıbbi bakım, giyim, ulaşım gibi masraflarımı karşılayabilmek için yardıma gereksinim duyuyorum.

62.4

9. Cocuğumun terapi, özel eğitim, bakım ve bu gibi masraflarımı karşılayabilmek için maddi yardıma gereksinim duyuyorum.

10. Çocuğum için gerekli olan özel araçları sağlayabilmek için maddi yardıma gereksinim duyuyorum.

39.5

\section{F3 Bilgi Gereksinimi}

11. Çocuğumla nasıl oynayacağım, nasıl konuşacağım hakkında daha fazla bilgiye gereksinim duyuyorum.

12. Çocuğumun durumu (özürü) hakkında daha fazla bilgiye gereksinim duyuyorum.

13. Çocuğuma bazı becerileri nasıl öğreteceğim konusunda daha fazla bilgiye gereksinim duyuyorum.

14. Çocuğumun davranışlarını nasıl kontrol edebileceğim konusunda daha fazla bilgiye gereksinim duyuyorum.

\section{F4 Çocuğun Durumunu Diğerlerine Açıklamak}

15. Eşimin, çocuğumun durumunu anlayabilmesi ve kabullenebilmesi için daha fazla yardıma gereksinim duyuyorum.

16. Çocuğumun durumunu kardeşlerine açıklayabilmek için daha fazla yardıma gereksinim duyuyorum.

17. Çocuğumun durumunu eşime ve eşimin ailesine açıklayabilmek için daha fazla yardıma gereksinim duyuyorum.

F5 Toplumsal Servisler

18. Beni ve çocuğumun gereksinimlerini anlayacak doktor bulmak için yardıma gereksinin duyuyorum. 
19. Çocuğuma yardımcı olabilecek diş hekimi bulmak için yardıma gereksinin duyuyorum.

20. Çocuğumun oğretmeni yada terapisti ile konuşabilmek için daha fazla zamana gereksinim duyuyorum.

21. Benim çocuğumla benzer ozellikte çocuğu olan anne-babalar hakkında yazılmış kitap, makale gibi materyalleri okumaya gereksinim duyuyorum.

22. Problemlerim hakkında konuşmak için duzenli olarak psikolojik danışman, sosyal çalışmacı, psikiyatrist, psikolog ile bir araya gelmek istiyorum.

49.8

\section{F6 Destek Gereksinimi}

23. Diğer ozùrlu çocuk anne-babalarıyla daha çok tanışmaya ve konuşmaya gereksinim duyuyorum.

25.4

24. Problemlerime çozum bulabilmek için dini górevlilerle konuşmaya daha çok gereksinim duyuyorum.

Tablo 4'deki verilere gore annelerin en fazla gereksinim belirttikleri alan aracın uçuncu boyutu olan "Bilgi Gereksinimi" boyutu olmuştur. Aracın bu boyutunda yer alan dort maddeyi de anneler en fazla gereksinim duyduklan maddeler (\% 60'ın uzerinde) olarak belirtmişlerdir. Bu boyutt d $\% 78.3$ ile "çocuğuma bazı becerileri nasıl oğreteceğim konusunda daha fazla bilgiye gereksinim duyuyorum" maddesi en fazla gereksinim duyulan madde olarak ilk sırada yer almıştır. Bunu \% 77.3 ile ikinci sırada "çocuğumla nasıl oynayacağım/ nasıl konuşacağım hakkında daha fazla bilgiye gereksinim duyuyorum" maddesi izlemiştir.

Aracin ikinci boyutu olan maddi gereksinimler grubu ikinci sırada en fazla gereksinim belirtilen alan olmuştur. Bu grupta \% 62.4 ile "yiyecek, ev kirası, tıbbi bakım, giyim, ulaşım gibi masraflarımı karşlayabilmek için yardıma gereksinim duyuyorum" maddesi ilk sırayı almaktadır. Bunu ikinci sırada \% 58.9 ile "çocuğumun gereksinimi olan oyuncakları alabilmek için yardıma gereksinim duyuyorum" maddesi izlemiştir. uçuncu sırada "toplumsal servisler" boyutundaki beş maddenin dordu en fazla gereksinim belirtilen maddeleri içermektedir. Bu boyutta \% 67.3 ile "benim çocuğumla benzer ozellikte çocuğu olan anne-babalar hakkında yazılmış kitap, makale gibi materyalleri okumaya gereksinim duyuyorum" maddesi, \% 64.7 ile "çocuğuma yardımcı olabilecek diş hekimi bulmak için yardıma gereksinim duyuyorum" maddesi \% 49.8 ile "problemlerim hakkınđa konuşmak için duzenli olarak psikolojik danışman, 
sosyal çalışmacı, psikiyatrist, psikolog ile biraraya gelmek istiyorum" maddesi ile bu boyutta en fazla gereksinim belirtilen maddeler olmuştur.

Destek gereksinimi boyutunda yer alan "problemlerime çözüm bulabilmek için, dini görevlilerle konuşmaya daha çok gereksinim duyuyorum" maddesi annelerin \% 55.1'inin "kesinlikle evet" olarak yanıtladığ1 madde olmuştur.

Ailenin işleyişi boyutundaki "problemlerimizi tartışmak ve çözümler bulabilmek için ailemin yardıma gereksinimi vardır" maddesinde annelerin \% 50'den fazlasının gereksinim belirttikleri görülmüştür.

\section{Annelerin En Az Gereksinim Duyduğu Alanlar:}

Annelerin AGBA'nın maddelerine "evet" olarak verdikleri yanıtlar incelendiğinde "ailemin ev işleri, çocuk bakımı ve diğer işleri kimlerin yapacağı hakkında karar verebilmek için 'ardıma gereksinimi vardır" maddesi $\% 20.4$ ile en az gereksinim duyulan madde olarak birinci sırada yer almaktadır. Ayrıca "çocuğumun terapi, özel eğitim, bakım ve bu gibi masraflarım karşılayabilmek için maddi yardıma gereksinim duyuyorum" maddesine annelerin \% 22.5 ile, çocuğun durumunu diğerlerine açıklamak grubundaki "çocuğumun durumunu eşime ve eşimin ailesine açıklayabilmek için daha fazla yardıma gereksinim duyuyorum" maddesi $\% 27.8$ ile, "ailem dinlenme, eğlenme etkinlikleri hakkunda karar vermek ve yapmak için yardıma gereksinim duymaktadır" maddesi \% 27.5 ile en az gereksinim duyulan maddeler olarak belirlenmiştir.

\section{III. Ạ̧ı Uçlu Sorulara Verilen Cevaplar:}

AGBA'nmn ikinci bölümünde yer alan "ailenizin en temel beş gereksinimini sıralayınız" açı uçlu sorusundan elde edilen veriler, I. bölümden elde edilen sonuçlarla karşılaştırılarak değerlendirilmiştir.

Açık uçlu soruda annelerin çoğunluğunun beş temel gereksinim yerine bir ya da iki gereksinim yazdıkları, bazı annelerin ise ayrıca hiç gereksinim belirtmedikleri gözlenmiştir. Bu bölümde annelerin ifade ettiği gereksinimler sıralanmış, annelerin temel gereksinim olarak ifade ettikleri cevapların 163 maddede toplandığı görülmüştür. Bu 163 gereksinimin 18'i (\%78.5) I. bölümde yer alan gereksinimlerden oluşmaktadır. 35 maddede ifade edilen yeni gereksinimlerin ise 13'ünün (\%37.14) işitme cihazlamnın devletçe karşlanması, 8'inin (\%22.8) servis (çocuğun okula rahat gidip gelebilmesi), 5 'inin (\%14.2) oturdukları semtte işitme 
engelliler için okul, 5 inin (\%14.2) gelecek endişelerinin giderilmesi ve 4'unun (\%11.4) ise işitme engelli okullarında teknolojik donanımın ve işitme eğitiminin sağlanması olarak sıralandığı gorulmektedir.

\section{Annelerin Gereksinimlerinin Demografik Özellikler Açısından İncelenmesi}

Araştırmanın bu aşamasında annelerin AGBA'dan aldıkları toplam puanlar ve her boyuta ilişkin puanları annenin yaş, eğitim, aile eğitimi alıp almama durumu ve çocuğun cinsiyet, yaş, işitme engeli derecesi gibi ozelliksler açısından incelenmiştir.

Annelerin AGBA'dan aldıkları toplam puanlar, annenin yaş durumuna gore incelendiğinde, anne yaşınn gereksinimler uzerinde etkili bir değışken olmadığı bulunmuştur $[\mathrm{F}(3,185)=0.8336, \mathrm{P}>.05]$.

Araçtan elde edilen toplam puanlar, annenın eğitim durumuna gore incelendiğinde, annelerin toplam puanlarının bu ozelliğe gore farklılaşmadığı bulunmuştur $[\mathrm{F}(3,178)=1.6929, \mathrm{P}>.05]$. Ayrıca AGBA'nın altı alt boyutunun annenin eğitim durumuna gore farklılaşıp farklılaşmadığı incelenmiş, annelerın bu altı gruba ilişkin puanlarının da eğitim durumuna gore farklılaşmadığ̀ bulunmuştur.

Annelerin AGBA'dan aldığı toplam puanlar, aile eğitımi alıp almama durumlarna gore incelenmiş, toplam puanların, annenin aile eğitimi alma durumuna gore farklılaşmadığ bulunmuştur $(t=0.39, \mathrm{P}>.05)$. Altı faktơrün her biri için yapılan t testi sonuçları da annelerin aile eğitimi alma durumlarının, bu faktorlere gore farklışamadığını ortaya koymuştur.

Işitme engelli çocuğun cinsiyeti açısından annelerin gereksinimlerinin farkılaşıp farklılaşmadı̆̆ incelenmiş, toplam puanların çocuğun cinsiyetine gore farklılaşmadığı bulunmuş̧tur $(t=1.88, P>.05)$. Ancak 6 faktor dikkate alınarak yaplan incelemede, AGBA'nın ikinci boyutu olan "maddi gereksinimlerde" annelerin belirttikleri gereksinimlerın, işitme engelli çocuğun cinsiyetine gore farklılaştığı bulunmuştur $(\mathrm{t}=4.36, \mathrm{P}<.01)$. Ortalama puanlar dikkate alındığında erkek çocuğa sahip annelerin daha fazla gereksinim belirttikleri goruimuştur.

Işitme engelli çocuğun yaşı açısından annelerin gereksinimlerinin farklılaşıp farklılaşmadığ incelenmiş, annelerin AGBA'dan aldığı toplam puanların, bu değişkene göre farklılaşmadığı bulunmuştur $(\mathrm{t}=0.68, \mathrm{P}>.05)$. Faktorler açısından yapılan incelemelerde, annelerin 
bazı faktorlere ilışkin gereksinimlerınin, çocuğun yaşına gore farkhllaştığı belirlenmiştir. Altı faktorden birinci faktor olan "ailenin işleyişi" $(\mathrm{t}=2.33, \mathrm{P}<.05)$ ile "çocuğun durumunu diğerlerıne açılamak" $(\mathrm{t}=2.43$, $\mathrm{P}<.05)$ ve "toplumsal servislere" ihışin annelerin gereksinmmlerinin, çocuğun yaşına gore farklılaştığı bulunmuştur $(t=2,23, P<.05)$. Ayrica altmci boyuttaki "destek gereksinimi" ni ifade eden gereksinimlerin de çocuğun yaşına gore farkhlaş̧tığı belirlenmiştir $(t=2.16, \mathrm{P}<.05)$.

Çocuğun işitme kaybı derecesi yonunden, annelerin gereksinimlerinin farkılaşıp farklılaşmadığı incelenmiş, annelerin AGBA'dan aldıkları toplam puanlarn $([F(4,167)=1.1283, P>.05])$ ve altı boyutunun herbirinden alınan puanların çocukların işitme kaybı derecelerine gore farkhlaşmadığı belirlenmişstir.

\section{TARTIŞMA}

$\mathrm{Bu}$ çalş̧mada işitme engelli çocuğa ve ailesine gerekli hizmetlerin sağlanabilmesi, ailenin çocuğunun eğitimıne etkili şekilde katılabilmesı için, oncelikle gereksinimlerinin belirlenmesi amaçlanmıştır. Bu nedenle once Bailey ve Simeonsson tarafindan gelıştırilen, Sucuoğlu (1995) tarafindan Turkçeye çevrilerek faktor analizi yapılan Aile Gereksinimlerı Belirleme Aracı, ayrı engel grubu olan işitme engelli çocuğa sahip ailelere uygulanarak yeniden faktor analizi yapılmış, aracin altı faktorde toplandığı, bazı alt maddelerin farklı boyutlarda yer aldığı gorulmekle birlikte, sonuçların aynı aracı zihinsel ve otistik çocuğu olan ailelerde uygulayan Sucuoğlu'nun (1995) çalışmasıyla paralellik gosterdiği bulunmuştur. Boylelıkle AGBA'nın işitme engelli çocuğu olan annelerı gereksinimlerini belirlemek amacıyla kullanılabileceği belirlenmiştir.

Aracın işitme engelli çocuğa sahip annelere uygulanması ile annelerin \%50'den fazlasının AGBA'nın birinci bolumundeki 14 madde içın en fazla gereksinim ıfade ettikleri gỏzlenmiştir. Aynı zamanda bu gereksinımlerın annelerin eğitim durumu, yaş ve aile eğitımi alma durumlarına gore değişmediği de belirlenmıştir. Bu bulgu, ailelere sağlanacak hizmetlerin içeriğinin ve niteliğinin belirlenmesinde onemli kabul edilmiştir.

Annelerin en fazla gereksinim duyduğu boyutun "Bilgi Gereksinimi" olduğu gozlenmiştır. Bu boyutta yer alan dort maddenin tumu de en fazla gereksinim duyulan ifadelerin yer aldığı maddelerdir. Bu gruptaki maddelerde, çocuğa yeni bir beceri kazandırabilmek, çocukla iletışim 
kurabilmek, çocuğun engeli ve çocuğun davramışlamn kontrol edebilme ile ilgili bilgi edinme konularında bilgi gereksinimleri ifade edilmektedir. Bu grup, Sucuoğlu'nun (1995) çalışmasında da en fazla gereksinim belirtilen grup olmuştur.

Ưlkemizde engelli çocuğu olduğu belirlenen aileleri bilgilendirme ve yönlendirme hizmetlerinin oldukça sinırlı olduğunun bilinmesiyle birlikte sınırlı sayıda yapılan çalışmalarda, ailelerin gereksinimlerinin karşılanmasımın ailedeki stresi azaltacağı, durumu daha kolay kabul edebilecekleri ve çocuğun eğitimine daha çok katkıda bulunabilecekleri görülmektedir. Ailelerin bilgi gereksinimlerini gidermeyi ve buradan yola çıkarak anne-baba katılımını arttırmayı hedefleyen programlardan ailelerin yararlandığı bir çok çalışmada gözlenmiştir (Boison, 1987; Bernstein ve Barta, 1988; Kargın, 1990; Sucuoğlu, Kanık ve Küçüker, 1992, 1994; Akçamete ve Kargın, 1996). Ancak bu çalışmada anne 'rin çoğunluğunun aile eğitiminden geçtiklerini belirtmelerine karşın, bu hizmetin bilgi gereksinimini gidermede etkili olmadığı görülmektedir. $\mathrm{Bu}$ durumun aile eğitimi programlarının içeriği ile ilgili olduğu düşünülmektedir.

Maddi gereksinimler boyutunda annelerin en yoğun gereksinimlerinin "yiyecek, ev kirası, tıbbi bakım, giyim, ulaşım gibi masrafları karşılayabilmek için yardıma gereksinim duyuyorum" maddesi ile "çocuğumun gereksinimi olan oyuncakları alabilmek için yardıma gerek duyuyorum" maddesi ve "çocuğumun gereksinimi olan oyuncakları alabilmek için yardıma gereksinim duyuyorum" maddesinde toplandığg gözlenmektedir. Öte yandan, bu grupta yer alan "çocuğumun terapi, özel eğitim, bakım ve bu gibi masraflarımı karşlayabilmek için maddi yardma gereksinim duyuyorum" maddesi en az gereksinim duyulan madde olarak belirtilmiştir. İşitme engelli çocukların sıkhkkla tıbbi bakım ve cihaz kullanmmna gereksinim duymalar, tıbbi bakımın ve cihaz donanımının pahalı oluşu ve bunların azının karşılanması aileyi genellikle maddi sorunlarla karşı karşıya bırakmaktadır. $\mathrm{Bu}$ nedenle, Sucuoğlu'nun (1995) zihinsel ve otistik çocuğu olan anne-babalarla yap̧tığı çalışmasında maddi gereksinimin ủçüncü sırada yer almış olmasına karşın, bu çalışmada ikinci sırada belirtilmiş olması işitme engelli çocukların annelerinin daha fazla maddi sorunlarla karşı karşıya oldukları şeklinde yorumlanabilir. Annelerin çocuğun terapi ve özel eğitime ilişkin masrafları karşlayabilmeleri için daha az maddi gereksinimi ifade etmeleri ise, araştırmanın uygulandığı anneler grubundaki tüm çocukların özel bir masrafi gerektirmeyen, devletçe açılmış, özel 
eğıtım kurumlarına yerleştırılmış olmasıyla açıklanabılır Ayrıca annelerın çoğunluğunun aıle eğıtımı aldıklarım belırtmış olmalarnna karşın, bilgı gereksinımlerının giderılememesı, cihaz donanımı, tedavı gibı daha oncelıklı maddı gereksınımlerının olması, alleierın çocuklarının okul sıstemı dışındakı ozel eğıtım hızmetlerınden yararlanmalarını engellemiş olabılır Bu nedenle anne-babaların oncel rklı maddı gereksinímlerının devlet ve gonullu kuruluşlar yardımıyla çozumlenmesı konusunda çalışmalar yapılması gerekmektedır Ancak bu gereksınımlerın gıderılmesı ıle arlelerın alternatıf eğıtım olanaklarım duşunmelenı ve çocuğunun eğıtımıne katılımları sağlanabılır

Toplumsal servisler boyutunda yer alan beş maddenın dordu annelerın "evet" olarak yanıtladıkları maddelerı ıçermektedır "Benım çocuğumla benzer ozellkkte olan anne-babalar hakkında yazılmış kitap, makale gibı materyallerı okumaya gereksınm duyuyorum" ıle "problemlerım hakkında konuşmak ıçın duzenh olarak psıkolojık danışman, sosyal çalışmacı, psıkıyatrıst, psıkolog ıle bıraraya gelmek ıstıyorum" maddelerı bu gruptakı en fazla gereksınımı ifade etmektedırler Işıtme engelh çocuğu olan anne babalarnn, çocuğun alleye katılımı nle stres ve kaygıı ıçınde oldukları, çocuklamna tanı konulduğu andan başlayarak engel durumu ile başetmede ozel bur yardıma gereksinim duyduklar durumu kabul edılmektedır (Beckman, 1983, Bubolz ve Whiren, 1984, Bernstemn ve Barta, 1988, Şen, 1991) Boıson (1987), 1şıtme engellı çocuğa sahıp allelerın tanılamadan sonrakı tepkılen ıle gereksınımlerın belırlemek uzere araştırmaya katılan 80 alleye bur anket uygulamıştır Araştırmanın sonucunda tum alleler teşhıste kendılerıne yapılacak rehberlık ve danışma hızmetlerı ıle ılk şoku atlatarak, çocuklarını daha kolay kabul edebıleceklermı ve ışıtme engelının gereklerm yerıne getırebıleceklerını belırtmışlerdır Anne babaların benzer problemı olan dığer anne babalarla biraraya geldıklen psıkologık danışma hızmetlerının, dığer anne babalara att yazılı materyallerın ve filmlerın sağlanmasının bu sorunlarıyla baş edebılmelerınde gereklı olduğu gorulmektedır Bu nedenle, tanılama aşamasında allenın psıkolojık ozelhklermnn de değerlendırılmesı ve profesyonel yardım almalarının ve diğer genel hızmetlernn sağlanması, arle-çocuk etkıleşımının daha olumiu gelı̧̧mesinde ve çevrenın alleden beklentılerının karşılanmasında etkilı olacaktir

Toplumsal Servisler boyutunda "annelerın \% 64 7'sinmn "evet" olarak yanıtladıkları bır dığer madde "çocuğuma yardınıı olabılecek dış hekımı bulmak ıçın yardıma gereksınım duyuyorum" maddesı olmuştur. Işıttme engellı çocuklarda dış sorunu olmadığ ya da en azından dığer çocuklar- 
dan bir farklılık gostermediği duşunuldưğunde, bu maddenin gereksinim olarak belirtilmesinin, doktor gereksininı ile genelleştirilebileceği, bu grupta böyle bir madde olmadığı için işaretlenmiş olabileceği soylenebilir.

Destek gereksinimi grubunda annelerin \% 55'inin "problemlerime çozúm bulabilmek için dini gorevlilerle konuşmaya daha çok gereksinim duyuyorum" maddesini "kesinlikle evet" olarak işaretledikleri gorulmektedir. Ayrıca bu grupta yer alan "problemlerimizi tartışmak ve çòzumler bulabilmek için ailemin yardıma gereksınimi vardır" "ailemın guç zamanlarda birbirlerinı nasıl destekleyeceklerini oğrenmek ıçin yardıma gereksinimi vardır" maddeleri en fazla gereksinim duyulan maddeler olarak ifade edilmiştir. Bu maddeler Toplumsal Servisler grubundaki gereksinimlerle bağlantılı olarak duşunulduğunde, ailelerin kendilerine destek olacak, aile ilişkilerini ve iletişimini geliştirecek uzman yardımına duydukları gereksinimi vurgulamaktadır. Annelerin büyùk çoğunluğunun eğitim durumlarının alt duzeyde oluşu, bu gereksinimin karşlanmasının onemini daha da arttırmaktadır.

Açık uçlu sorularn yanıtları incelendiğinde, annelerin buyuk çoğunluğunun birinci bolumdeki maddelerle ortuşen gereksınmmleri ifade ettikleri gozlenmiştir. Ozel gereksinim olarak belirttikleri en temel gereksinim "çocuğunun işitme cihazının devletçe karşlanması" olmuştur. Işitme engelli çocukların eğitimlerinin mutlaka cihaz kullanımını gerektirmesi, cihaz ucretlerinin giderek artması ve ailenin maddi gucu ile karşılanmasının olanaksızlaşması, devletin ancak bazı kamu ve işçi personeline, bu miktarın bir kısmını karşılıyor olması bu maddenin onemli bir gereksinimi ifade ettiğini gostermektedir ( $\mathrm{Bu}$ madde I. bolumde yer almadı̆̆ için ozel gereksinim olarak belirtilmiştir). Gelişmiş ulkelerde cihaz giderinin tumu devletçe karşılandığı gibj, arızaliandığında çocuğun eğitiminde bir aksama olmaması için ek cihaz da sağlanmaktadxx. Ulkemizde boylesi bir uygulamanun olmayışı ve bu gereksinimin ancak bir kısmının sağlanıyor olması nedeniyle, alım ve onarım giderlerinin karşılanmasında aileler zorlanmaktadırlar. Bu yuzden gereğine inansa bile birçok aile çocuğunu cihazlandırmaktan kaçınmaktadır.

Ailelerin ikincil olarak belirttikleri ozel gereksinim "servis" sağlanması ve bu gereksinimle bağlantılı duşunulebilecek bir gereksinim de oturdukları semtte işitme engelliler okulunun olmasıdır. Servis, Sucuoğlu'nun (1995) çalışmasında da başlıca ozel gereksinim olarak ifade edilmektedir. Gelişmiş ulkelerde ozel gereksinimli oğrencilerin ulaşım sorunlarının okul tarafindan giderilmesi yasal zorunluluktur 
(Fiscus ve Mandell, 1983). Ulkemizde ise işitme engelli çocukların devam ettikleri kurumların son derecede sinırlı ve ailelerin oturduğu semtlerden uzak olması, okulların servislerinin bulunmayışı aileleri boyle bır sorunla karşı karşıya bırakmaktadır. Bu nedenle ozel eğitimle ilgili kurum ve kuruluşlarnn bu gereksinımı karşılamaya yonelik onlemler almaları, dolayısıyla daha fazla çocuğun özel eğitimden yararlanmasının sağlanması gerekmektedir.

Açık uçlu sorularda belirtilen temel gereksinimlerden biri de işitme engelli çocuklamn devam ettikleri okullarda teknolojik donanımın sağlanmasıdır. Ailelerin, okulların grup işitme cihazlarıyla donanımılımının sağlanmasını gereksinim olarak belirtmeleri, onların çocukları ıçın uygun eğitimin ışitsel becerilerın geliştirilmesiyle sağlanabileı ığini benimsediklerin gostermesi açısından onemli bulunmuştur.

Açık uçlu sorularda annelerin çocuklarının geleceğine ılişkıı endişelerinin giderilmesini de temel bir gereksinim olarak ifade ettikleri gorulmektedir. Engelli çocuğa sahip ailelerin kaygı ve endişe duz vlerinin çeşitli faktorlerden etkilenmekle birlikte, normal çocuk anne babalarından daha yuksek olduğu ve geleceğe ilişkın kayglar taşıdıklan kabul edilmektedir (Akkok, 1989). Ulkemizde bu konudaki hizmetlerın sınırlı oluşu, ailelerin bu tur sorunlarla başa çıkmalannı guçleştirmektedir. Bu konu ıle ilgili olarak devlet ve gonullu kuruluşların rehabilitasyon hizmetlerinı yaygınlaştırmaya çalışmaları yararlı olacaktır.

Işitme engelli çocuğu olan annelenn belirttikleri gereksinimlere etki eden faktorleri ortaya çıarmak amacıyla bu gereksinimler, annelerin ve çocukların demografik ozellikleri ile karşılaştırılmış ve sonuçta çocuklamn cinsiyetinin yalnızca maddi gereksinim boyutunda farkhlaştığı, erkek çocuğa sahip annelerin daha çok maddı gereksinim belirttikleri gozlenmiştir. Bu bulgu geleceğe ilişkin endişe bulgusu ile birlikte duşunulmelidir. Ozellikle ulkemizde $\mathrm{k} ı \mathrm{z}$ çocuklam içın de aynı endişe duyulmakla birlikte, erkek çocuklarının uretici konumda olmamalan aileleri endişelendirmektedir. Bu nedenle duzenlenecek eğitim programlarının, çocukları mesleğe hazırlama ve meslek kazandırmayı hedefliyor olması, ailelerin maddi sorunlarının azaltılması açısından gerekli gơrulmektedır. Bunun için işitme engelli çocuklar için duzenlenecek programlar "yaşam boyu eğitim" çerçevesinde ele alınmalı ve surdurulmelidir.

Aracın beş boyutunda annelerin gereksinimlerınin çocuğunun yaşına gore farklılaşmadığı, ancak "ailenin işleyişine" iliş̧in gereksinimlerinin, çocuğun yaşı arttıkça fazlalaştığı gozlenmiştir. Bu durum, çocuğunun engellilığinin getirdiği sorunlarla, içinde bulunduğu gelişim- 
sel dönemlerin ortak etkisinin sonucu olarak yorumlanabilir. Ailelerin çocuğuna ilişkin çeşitli kararlar verme durumda olmalarının, aile içi ilişkileri etkilediğini, ailelerin daha çok yardım gereksinimi içinđe olduklarını göstermesi açısından önemlidir.

Aynı zamanda destek gereksiniminin, çocuğun yaşına göre farklılaştığı, çocuğun yaşı küçüldükç̧e ailelerin daha çok destek gereksinimi içinde olduklar görülmektedir. Bu nedenle, işitme engelli çocuklar için hazırlanacak programların çocukların özelliklerini ve gereksinimlerini dikkate alarak düzenlendiğinde, farklı yaş gruplamna işitme engelli çocuğu olan ailelerin gereksinimlerini de karşılayabileceği düşünülmektedir. Böylelikle ailenin eğitime katılımları da arttırılabilecektir.

Sonuç olarak, işitme engelli çocuğu olan anne-babalar için hazırlanacak terapi ve eğitim programlarında aile gereksinimlerinin bilinmesi, programın başarısını ve ailenin katılımını arttırmada etkili olacaktır. Bu nedenle, alana kazandırılmış olan bu araçla anne-baba gereksinimlerinin belirlenmesi, özel ve genel eğitim kurumlarının program oluşturmada bu gereksinimleri karşılayabilecek hazırlık ve donanımları yapmaları gerekli görülmektedir.

\section{KAYNAKÇA}

Akkök, F. (1989). Özürlü bir çocuğa sahip anne-babalarm kaygn ve endişe düzeyini ölçme aracının geçerlik ve güvenirlik çalışması. Psikoloji Dergisi, 7 (23), 26-39

Akçamete, G., Kargın, T. (1996). İşitme engelli çocukların eğitiminde erken eğitim programlarınm etkililiğinin incelenmesi. A. Ü. Araştırma Fonu Projesi Raporu.

Bailey, D.B., Simeonsson R.J (1988). Assessing needs of families handicapped infants. The Journal of Special Education. 22(1), 117-127

Beckman, P (1983). Influence of selected child characteristics on stress in families of handicapped infants. American Journal of Mental Deficiency, 88(2), 150-156

Bernstein, A (1993). A school-based parent-infant program. The first step in the educational process. The Volta Review, 95 (5), 75-84.

Bernstein, E. M., Barta, L (1988). What do parents want in parent education? American Annals of Deaf, July, 235-246.

Boison, B. K. (1987). Diagnosis of deafness. International Journal of Rehabilitation Research, 10 (2), 220-224

Bubolz, M.M., Whiren, P.A (1984). The family of the handicapped: An ecological model for policy and practice. Family Relations, January, 5-12 
Cunningham, $C$ (1985) Trainıng and education approaches for parents of children with special needs British Journal of Medical Psychology, 58, 285-305

Dunst, J C , Johanson, C , Trivette M C , Hamby, D (1991) Family-oriented early intervention policies and practices Family- centered or not? Exceptional Children, October, November, 115-126

Fiscus E D , Mandell, C J (1983) Developing individualized education programs St Paul West Publishing Company

Fitzgerald, M D , Fischer, M R (1987) A famly involvement model for hearing-imparred infants Topics of Language Disorders, 7(3), 1-18

Kargın, T (1990) Eğitsel yaklașımlı aile rehberliğinin işitme engeli çocukların sozel iletişim becerilerine etkisi. Yayınlanmamış Yuksek Lısans Tezı A U Sosyal Bılımler Enstıtusu, Ankara

MC Loughling AJ, Rena, BL (1990) Assessing special students. Columbus Merril Publishmg Company

Meyers, C E , Blacher, J (1987) Parents perceptions of schooling for severely handıcapped chıldren Home and famıly variables Exceptional Children, $53(5), 441-449$

Robinson, C C, Rosenberg A S, Beckman, P S (1988) Parent involvement in early childhood special education: Birth to three. Ed Jordan J B , Gallagher J J , Hutinger P L, Karnes M B , ERIC

Şen, M (1991) Işitme engelli kardeşi olan çocukların psikolojik durumlarının incelenmesi. Yayınlanmamış Yuksek Lısans Tezı A U Sosyal Bilımler Enstitusu, Ankara

Sucuoğlu, B , (1995) Ozurlu çocuğu olan anne-babaların gereksınımlerının belırlenmesı Çocuk ve Gençlik Ruh Sağlığı Dergisi, 2 (1), 10-18

Sucuoğlu, B , Kuçuker, S , Kanık, N (1992) Ozel eğtımde anne-baba programları (ornek çalısma) A.U. Eğitim Bilimleri Fakultesi Dergisi, 24 (2), $321-538$

Sucuoğlu, B , Kuçuker, S , Kanık N (1994) Anne babalara oğretme becerılerunun kazandirulması Psikoloji Dergisi, 9 (31), 36-43

Weber, J L, Stoneman, F (1986) Parental nonparticipation in program planıng for mentally retarded children An empirical investigation Applied Research in Mental Retardation, 7, 359-369

Winton, $\mathrm{P}(1985)$ Effective strategies for involving families in intervention efforts Focus on Exceptional Children, 19 (2), 3-10 